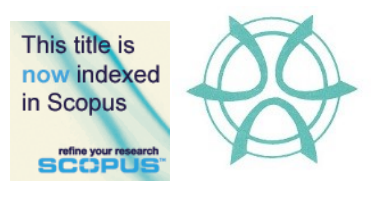

PLANNING MALAYSIA:

Journal of the Malaysian Institute of Planners

VOLUME 19 ISSUE 3 (2021), Page 317 - 325

\title{
WAQF LAND DEVELOPMENT APPROACHES AND PRACTICES IN THE STATE ISLAMIC RELIGIOUS COUNCILS
}

\author{
Mohd Arif Mat Hassan', Anuar Alias², Siti Mashitoh Mahamood ${ }^{3}$ \& Feroz De \\ Costa $^{4}$ \\ ${ }^{1,2}$ Faculty of Built Environment \\ UNIVERSITI MALAYA \\ ${ }^{3}$ Academy of Islamic Studies \\ UNIVERSITI MALAYA \\ ${ }^{4}$ Department of Communication, Faculty of Modern Languages and \\ Communication \\ UNIVERSITI PUTRA MALAYSIA
}

\begin{abstract}
Waqf land is a religious property that is provided as a charity act by a donor and placed under the jurisdiction of the State Islamic Religious Councils (SIRCs). The SIRCs are the sole trustees in charge of governing, managing, and developing these properties. SIRCs have been working to develop waqf lands through a variety of projects and ways that adhere to best practices and a sound management system. However, the waqf's potential for greater outcomes is yet to be optimised. This research has reviewed the literature of waqf land development approaches and practices in Malaysia and it has tabled the significant development approaches that can be implemented by the SIRC. These approaches and practices may overcome the issues and challenges faced by the SIRCs in developing waqf land.
\end{abstract}

Keyword: Waqf Land, Land Development, Development Approaches \& Practices, State Islamic Religious Councils (SIRCs)

\footnotetext{
2 Associate Professor at Faculty of Built Environment, University ofMalaya. Email: anuar@um.edu.my.
} 
Mohd Arif Mat Hassan, Anuar Alias, Siti Mashitoh Mahamood \& Feroz De Costa

Waqf Land Development Approaches and Practices in The State Islamic Religious Councils

\section{INTRODUCTION}

Land is a limited resource and it is one of the main factors of production. It plays a large role in the economic growth of a country and also satisfies humans' unlimited needs and wants. Rapid developments lead to high demand for land. Hence, it should be managed effectively within the scarcity of land settings. This will unlock the value of the land to its highest and best use. This study focuses on the development of religious land known as waqf land by the State Islamic Religious Councils (SIRCs).

SIRC is a sole trustee of waqf land in Malaysia according to The Federal Constitution's Ninth Schedule, List II (State List). They are authorised to manage the waqf land within their state jurisdiction with the best standard of practice and suitable management system according to Islamic law. Previous literature has raised several issues and challenges face by SIRCs in developing land under their jurisdiction. Various efforts have been taken by the SIRCs and other recognised institutions to overcome these challenges but not all of the states are able to perform well in developing waqf lands.

Besides the SIRCs, there are also Federal Agencies involve in waqf land development in Malaysia. The agencies under the Prime Minister's Department highly involved with SIRCs are Jabatan Wakaf, Zakat \& Haji (JAWHAR), and Yayasan Wakaf Malaysia (YWM). These agencies support the SIRCs in accomplishing this potential in a more orderly and efficient way. It is noted that these agencies are more of an active complementary agency and is not an actual authority because land is a state matter. JAWHAR and YWM have embarked on several projects in collaboration with the SIRCs to develop waqf land. According to JAWHAR, there are a few high-impact waqf projects that have been established in various states in Malaysia.

\section{LITERATURE REVIEW}

Waqf is a word in the Arabic language that means "stop, contain, or preserve". It is an act of philanthropy and it is a charitable endowment in Islamic law. A waqf land is a piece of land voluntarily donated by the donor as a charitable act for the social and economic development of Muslims and has strict principles such as "perpetuity, inalienability, and irrevocability" (Khaf, 1998). Among the contribution of waqf to social and economic development is that waqf has the capacity to provide affordable homes for the underprivileged and needy (Rashid, et al., 2018; Rashid, et al., 2019).

Waqf land is categorised into two, i.e "waqf am" and "waqf khas" according to its purpose. Waqf am refers to waqf land that has been endowed without any specific purpose and it is dedicated to the general welfare without stipulating any condition or any particular beneficiary. In contrast, waqf khas has a specific charitable purpose or special beneficiaries that have been precisely declared by the donor. Normally, the donor dedicated "waqf khas" for the 
development of mosques, orphanage homes, religious schools, cemeteries, etc. Meanwhile, waqf am or general waqf can be developed into any type of development as long as it can benefit the ummah (Mahamood, 2006).

According to JAWHAR, the number of waqf lands recorded has been increasing over the years. In 2013, there were 4,524 lots of waqf land with a total area of 11,092 hectares worth RM99,329,171. In 2015, it had gradually increased to 5,740 lots with a total area of 16,751 hectares worth RM111,413,890. Data from JAWHAR tabled the staggering increase to 14,356 lots with a total area of 30,888.9 hectares (Mahmood, Mustaffha, Hameed \& Johari, 2017). These huge numbers however do not include the unrecorded Waqf land. There are approximately 30 per cent of unrecorded Waqf lands and the actual size, location, and ownership of the waqf land are still unknown (Siraj, 2012). According to the former director of JAWHAR, there is 99.28 per cent of undeveloped and idle waqf land (Thaker \& Pitchay, 2018). The shortage of financial resources has led to a huge percentage of waqf land remained undeveloped (Ismail, Salim \& Hanafiah, 2015; Jalil, Yaacob, Omar, Ridza \& Fadzli, 2019).

The SIRCs hold the accountability to manage the waqf land. These include the power to develop the said land. Waqf land development will improve Muslims' socioeconomic conditions by allowing them to participate in and benefit from economic development initiatives while remaining compliant with Syariah.

\section{METHODOLOGY}

This research used content analysis as the qualitative approach. The systematic literature review (SLR) method has been used in this study. Research through literature review can be described as "a form of research that reviews, critiques, and synthesizes representative literature on a topic in an integrated way such that frameworks and perspectives on the topic are generated" (Torraco, 2005).

There are four (4) stages involved in conducting SLR. The process started with the selection of databases in stage 1. Prominent databases such as Scopus and Web of Science (WoS) were identified. These databases were chosen because of their robustness and it covers many fields of studies related to this research including social science, arts, and humanities, economics, finance, business, management, Islamic studies, etc.

The $2^{\text {nd }}$ stage is the keyword search configuration. Selecting the articles involve the identification of keyword and develop the search configuration. The search configuration for Scopus is TITLE-ABS-KEY ("Wakaf Land" OR "Waqf Land" OR "Awqaf Land"). Meanwhile, the search configuration for WoS is TS = ("Wakaf Land" OR "Waqf Land" OR "Awqaf Land"). In total, 51 articles were retrieved from the Scopus and WoS in this $2^{\text {nd }}$ stage. 
Mohd Arif Mat Hassan, Anuar Alias, Siti Mashitoh Mahamood \& Feroz De Costa

Waqf Land Development Approaches and Practices in The State Islamic Religious Councils

The $3^{\text {rd }}$ Stage is filtering the articles. The articles were filtered for duplication. 13 duplicate articles were omitted. The process was further refined for the remaining 38 articles. There were then reviewed for the inclusion and exclusion criteria. The review focused on the publication date, language, subject area, and specifically on the articles written in the areas of land development under the SIRCs jurisdiction.

After filtering, 16 articles remain and proceed to the $4^{\text {th }}$ Stage. 16 full articles were then carefully accessed. After reading the abstracts, the data were obtained. Next, the themes and sub-themes were detected by exhaustively reading the full articles. The qualitative analysis was then executed by the means of content analysis to identify themes related to Waqf land development tools and practices in Malaysia.

Articles were then further analysed through a coding process based on common characteristics. Thematic analysis was conducted in developing the appropriate themes and the sub-themes. The articles were analysed using a sophisticated Qualitative Data Analysis software called ATLAS.ti. This software finds all the keywords and phrases related to the subject matter. This approach is looking for patterns, threads, constructs, and commonalities. This data analysis technique enables the identification of key issues and challenges discussed in the articles using coding, grouping, and networking.

\section{FINDINGS}

This research has been able to provide results from the Qualitative Data Analysis using Systematic Literature Review (SLR) with the assistance of the ATLAS.ti. software. The list of the 16 articles according to the titles are as in Table 1. Further analysis of the publication year from 2009 to 2019 found that there is no article related to this study indexed in Scopus and Web of Science in the years 2009, 2012, and 2014. The average number of articles published is less than 2 articles annually and the highest number of articles published is 4 for the year 2015 and 2018. 
PLANNING MALAYSIA

Journal of the Malaysia Institute of Planners (2021)

Table 1: List of articles used in the SLR

\begin{tabular}{|c|c|}
\hline No. & Title \\
\hline 1. & A Comparative Study of Waqf management in Malaysia \\
\hline 2. & $\begin{array}{l}\text { Acquisition of Waqf Lands by the State Authority: A Case Study of Land } \\
\text { Acquisition in Terengganu }\end{array}$ \\
\hline 3. & $\begin{array}{l}\text { Administration and Management of Waqf Land in Malaysia: Issues and } \\
\text { Solutions }\end{array}$ \\
\hline 4. & $\begin{array}{l}\text { Asopting Al-Hikr Long Term Lease Financing for Waqf and State Lands } \\
\text { in Malaysia to Provide Affordable Public Housing }\end{array}$ \\
\hline 5. & $\begin{array}{l}\text { Application of the Build, Operate, Transfer (BOT) Contract as a Means of } \\
\text { Financing Development of Waqf Land: Malaysian Experience }\end{array}$ \\
\hline 6. & Classification and Prioritaztion of Waqf Lands: A Selangor Case \\
\hline 7. & $\begin{array}{l}\text { Compulsaru Acquisition of Waqf Land by the State Authorities: } \\
\text { Compensation Versus Substitution }\end{array}$ \\
\hline 8. & $\begin{array}{l}\text { Cooperative-Waqf Model: A Proposal to Develop Idle Waqf Lands in } \\
\text { Malaysia }\end{array}$ \\
\hline 9. & $\begin{array}{l}\text { Developing Waqf Land Through Crowdfunding-Waqf Model (CWM): } \\
\text { The Case of Malaysia }\end{array}$ \\
\hline 10. & $\begin{array}{l}\text { Factors Influencing the Adoption of the Crowdfunding-Waqf Model } \\
(\mathrm{CWM}) \text { in the Waqf Land Development }\end{array}$ \\
\hline 11. & $\begin{array}{l}\text { Factors Influencing the Behavorial Intentions of Muslim Employees to } \\
\text { Contribute to Cash-Waqf Through Salary Deductions }\end{array}$ \\
\hline 12. & Integrated Framework for Development on Waqf Land in Pulau Pinang \\
\hline 13. & $\begin{array}{l}\text { Maqasidic Approach in the Management of Waqf Property: A Study with } \\
\text { Reference to Malaysian Contemporary Issues }\end{array}$ \\
\hline 14. & $\begin{array}{l}\text { Modeling Crowdfunders' Behavorial Intention to Adopt the } \\
\text { Crowdfunding-Waqf Model (CWM) in Malaysia: The Theory of the } \\
\text { Technology Acceptance Model (TAM) }\end{array}$ \\
\hline 15. & $\begin{array}{l}\text { Substitution of Waqf Properties (Istibdal) in Malaysia: Statutory } \\
\text { Provisions and Implementations }\end{array}$ \\
\hline 16. & Waqf Private Property Trust Fund as Property Unlock Initiative \\
\hline
\end{tabular}

Sixteen selected articles have been systematically analysed. This study has identified four (4) themes related to the waqf development tools and practices in Malaysia. The breakdown of these themes according to the number of articles is as follows:

Table 2: Waqf land development approaches and practices discussed in the articles

\begin{tabular}{|l|l|l|}
\hline No. & Approaches \& Practices & Number of articles \\
\hline 1 & Joint-venture \& Partnership & 2 \\
\hline 2 & Government Assistance & 4 \\
\hline 3 & Public Participation & 6 \\
\hline 4 & Internal Management (SIRCs) & 4 \\
\hline
\end{tabular}

Source: Authors' ATLAS.ti Analysis 
Mohd Arif Mat Hassan, Anuar Alias, Siti Mashitoh Mahamood \& Feroz De Costa

Waqf Land Development Approaches and Practices in The State Islamic Religious Councils

Most of the articles used in this study discussed public participation in waqf land development. Besides self-initiatives, the SIRCs also involved the government in assisting them to develop waqf land. There are four (4) articles that discussed these approaches. Only two (2) articles highlight joint-venture and partnership in their article. Further details on the approaches and practices by the SIRCs are as follows;

\section{THEME 1. JOINT VENTURE AND PARTNERSHIP}

The SIRCs have established smart partnerships or joint ventures in developing land under their jurisdiction. This joint ventures and partnerships have been done with interested parties such as individuals, federal departments, state agencies, corporate institutions, financial institutions, and private firms in monetary forms and sharing expertise. Joint ventures between the SIRCs and the interested parties are based on the principles of mudharabah or musharakah. These principles enable the parties involved to receive profit according to the agreed ratio (Abdullah \& Meera, 2018; Jalil et al., 2019).

This joint venture and partnership with an interested party can be initiated because SIRCs don't have to contribute huge capital because it acts as the 'owner' of the land. There are two (2) local and one (1) overseas examples of joint-venture projects highlighted. The first example is JV between SIRC of Penang (MAINPP) with UDA Holding Berhad in developing housing schemes in Seberang Jaya, Pulau Pinang (Pitchay, Thaker, Mydin, Azhar \& Latiff, 2018). The second example is JV between SIRC of Federal Territory (MAIWP) and Lembaga Tabung Haji subsidiary (TH Technologies) in developing a purposebuilt office known as Menara Imarah Wakaf in Kuala Lumpur using a BuiltOperate-Transfer (BOT) contract (Mohd Noor \& Yunus, 2012). The overseas example given by Pitchay, Meera \& Saleem (2015) is the joint venture between King Abdel Aziz waqf (KAAW) with Bin Laden Group under a BOT contract in developing ZamZam Tower in Mekkah which consists of a shopping complex, a shopping mall, and hotels. These joint ventures involved financial institutions in financing the projects.

\section{THEME 2. GOVERNMENT ASSISTANCE}

Government assistance can be through funding the capital and facilitating the land development in terms of advice and expertise. The majority of the works of literature point out that SIRCs are having a significant challenge in developing land under their jurisdiction because of the insufficient fund and lack of expertise (Abdullah \& Meera, 2018; Awang, Hamid, Nazli \& Lotpi, 2017; Salleh, Hamid, Harun \& Ghani, 2015; Thaker \& Pitchay, 2018).

The federal government of Malaysia has established the Department of Awqaf, Zakat, and Hajj (JAWHAR) and Yayasan Wakaf Malaysia (YWM) to coordinate 
the development of waqf properties by the SIRCs. It also aids, facilitates, and complements SIRC initiatives to improve waqf administration, management, and development efficiency and effectiveness. JAWHAR \& YWM are also responsible for observing and assisting SIRCs development projects if the project is failed to complete due to a shortage of financial resources and expertise. These organisations are in charge of administering and managing waqf-related affairs (Thaker \& Pitchay, 2018).

According to JAWHAR, their JV programs with the SIRCs called Waqf Property Development Program has a total of 17 large scale and high impact projects involves a total cost of RM290.25 million with a total land area of 23.771 hectares. These JVs is funded by the federal government from the Malaysia Plan (RMK) allocation. The federal government becomes the main source of funding to the SIRCs for developing waqf land through many projects and developments. (Thanker \& Pitchay 2018). JAWHAR also published several manuals for SIRCs to improve their knowledge and practices. Six (6) manuals and guidelines have been produced to streamline the process and procedure of land development by SIRCs. The notable manual is 'Waqf Lands Administration Manual 2010' (Harun, Hamid, Salleh \& Bidin, 2017).

\section{THEME 3. PUBLIC PARTICIPATION}

Besides government assistance, public participation is equally important in waqf land development. The Malaysian Plan allotted some funds to the SIRCs, however, the sum allotted is insufficient to develop a large area of waqf land (Jalil et al., 2019).

Participation from the public can be done through contribution in terms of monetary (cash). Cash waqf is considered a crowdfunding method because it pools money from the public to fund waqf land development (Isa, Ali \& Harun, 2011; Jalil et al., 2019; Thaker \& Pitchay, 2018). The cash waqf concept received a soft reaction from the public but it was found to be more realistic to practise since it can be done in any amount and it is low compared to endow property or land as waqf (Jalil et al., 2019). Cash waqf can be done online and offline at various SIRCs platforms.

The public can also participate through corporate waqf by buying shares issued by corporate waqf entities. Johor Corporation (JCorp) launched the first corporate waqf in Malaysia by issuing its company's shares as Waqf in 2006. Meanwhile, SIRC of Selangor (MAIS) issued Selangor Share Scheme with the same purpose which is to elevate public participation in cash waqf by purchasing the share units (Isa et al., 2011; Jalil et al., 2019).

\section{THEME 4. INTERNAL MANAGEMENT}

SIRCs can self-develop lands under their jurisdiction using internal funds and expertise. The development project can be managed internally. Normally the type of 
Mohd Arif Mat Hassan, Anuar Alias, Siti Mashitoh Mahamood \& Feroz De Costa

Waqf Land Development Approaches and Practices in The State Islamic Religious Councils

development involve is a small-scale project such as constructing single-storey shops or bazaars for rental. The internal funds within SIRCs jurisdiction are money from the rental of premises, cash waqf from the public, proceed from istibdal, zakat fund allocation, etc. (Harun et al., 2017; Hisham, Jaseran \& Jusoff, 2013; Salleh et al., 2015)

Some SIRCs have established subsidiaries known as "Perbadanan" or "Corporation" responsible for the administration and management of waqf-related concerns. States that have established the entities are Selangor, Negeri Sembilan, and Johor. In 2011, MAIS formed Perbadanan Wakaf Selangor (PWS), a subsidiary that focuses on collecting cash waqf as an in-house financing source (Pitchay et al., 2015; Thaker \& Pitchay, 2018).

\section{CONCLUSION}

The issue with underdeveloped land under SIRCs jurisdiction is mainly because of insufficient funds (capital). Based on this study, there are four (4) themes of approaches and practices that have been adopted by the SIRCs in developing religious land in their state. Besides self-initiative, SIRC needs assistance from the federal government, private companies, developers, and public participation to improve its role as an effective sole trustee. There are a few rooms for improvement for the SIRCs to overcome any challenges related to land development. More continuous campaigns and promotion needed to be done to increase public awareness and participation in waqf. SIRCs have to maintain the synergy and strategic collaboration with the related parties including collaboration between SIRCs. Internally, SIRCs can improve their management system using an updated database, ICT upgrade, hiring professional experts, and strengthening the organizational structure. With all the effective approaches and best practices, SIRCs may strengthen and reform waqf administration in Malaysia and improve the economy of the Ummah.

\section{REFERENCES}

Abdullah, A., \& Meera, A.K.M. (2018). Adopting Al-Hikr long term lease financing for waqf and state lands in Malaysia to provide affordable public housing. Al-Shajarah: Journal of the International Institute of Islamic Thought and Civilization (ISTAC), 1-42.

Awang, M.B., Hamid, N.A., Nazli, I., \& Mohd Lotpi, M.Y. (2017). Maqasidic approach in the management of waqf property: A study with reference to Malaysian contemporary issues. Pertanika Journal of Social Sciences and Humanities, 25, 301-308.

Harun, N., Hamid, N.A., Salleh, K., \& Bidin, A. (2017). Acquisition of waqf lands by the State Authority: A case study of land acquisition in Terengganu. Pertanika Journal of Social Sciences and Humanities, 25, 281-292.

Hisham, S.H.A.J., Jaseran, H.A., \& Jusoff, K. (2013). Substitution of waqf properties (istibdal) in Malaysia: Statutory provisions and implementations. Middle-East Journal of Scientific Research, 13(13), 23-27. 
Isa, Z.M., Ali, N., \& Harun, R. (2011). A comparative study of waqf management in Malaysia. In International Conference on Sociality and Economics Development, 10, 561-565.

Ismail, C.Z., Salim, N.J., \& Hanafiah, N.J.A. (2015). Administration and management of waqf land in Malaysia: Issues and solutions. Mediterranean Journal of Social Sciences, 6(4), 613.

Jalil, R. A., Yaacob, A.C., Omar, I., Ridza, B. H. M., \& Fadzli, S. Z. (2019). Waqf private property trust fund as property unlock initiative. In IOP Conference Series: Materials Science and Engineering, 620 (1).

Kahf, M. (1998). Financing development of awqaf properties. Paper presented at the Seminar on Development of Awqaf by IRTI, Kuala Lumpur. Retrieved June 6, 2018

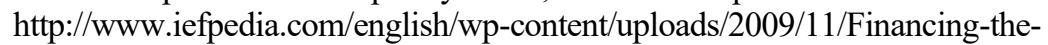
Development-of-Awqaf-Property.pdf

Mahamood, S.M. (2006). Waqf in Malaysia, Legal and Administrative Perspective. Kuala Lumpur: UM Press.

Mahmood, R.H., Mustaffha, N., Hameed, L.B.M., \& Johari, N. (2017). Pengurusan wakaf di Malaysia: Isu dan cabaran. In Proceeding of the 4th International Conference on Management and Muamalah, 2017(9).

Mohd Noor, A., \& Yunus, S.M. (2012). The application of Build, Operate, Transfer (BOT) contract as a mode of financing in developing waqf land: Malaysian experience. Joint Ventures in Construction 2: Contract, Governance, Performance and Risk. January 2012, 49-64

Pitchay, A.A., Meera, A.K.M, \& Saleem, M.Y. (2015). Factors influencing the behavioral intentions of Muslim employees to contribute to cash-waqf through salary deductions. Journal of King Abdulaziz University: Islamic Economics, 28(1).

Pitchay, A.A., Thaker, M.A.M.T., Mydin, A.A., Azhar, Z., \& Latiff, A.R.A. (2018) Cooperative-waqf model: a proposal to develop idle waqf lands in Malaysia. ISRA International Journal of Islamic Finance.

Rashid, K. A., Fauzi, P. N. F. N. M., \& Hasan, S. F. (2018). Meeting housing needs of the poor and needy Muslims through Zakat and Wakaf. Planning Malaysia, 16(7).

Rashid, K. A., Hasan, S. F., Fauzi, P. N. F. N. M., Aripin, S., \& Sarkawi, A. A. (2019). Zakat and wakaf funded housing for the poor and needy-an analysis of the zakat and wakaf authorities roles from the authorities' perspectives. Planning Malaysia, 17(9).

Salleh, K., Hamid, N.A., Harun, N., \& Ghani, M.N. (2015). Compulsory acquisition of waqf land by the state authorities: compensation versus substitution. Pertanika Journal of Social Science and Humanities, 23, 39-50.

Siraj. S.A. (2012). An empirical investigation into the accounting, accountability and effectiveness of waqf management in the State Islamic Religious Councils (SIRCS) in Malaysia. (Doctoral dissertation, Cardiff University, 2012)

Thaker, M.A.M.T., \& Pitchay, A.A. (2018). Developing waqf land through crowdfundingwaqf model (CWM): the case of Malaysia. Journal of Islamic Accounting and Business Research. 9 (3), 448-456.

Torraco, R.J. (2005). Writing Integrative Literature Reviews: Guidelines and Examples. Human Resource Development Review, 4(3), 356-367. https://doi.org/10.1177/1534484305278283

Received: $12^{\text {th }}$ July 2021 . Accepted: $17^{\text {th }}$ Sept 2021 